\title{
Genotoxic Studies Performed After Radiofrequency Radiation Exposure
}

\author{
Radyofrekans Radyasyon ve Genotoksik Etki Çalışmaları
}

\author{
Neslihan Gurbuz ${ }^{1}$, Bahriye Sirav ${ }^{2,3}$, Nesrin Seyhan ${ }^{2,3}$
}

${ }^{1}$ Gazi University Faculty of Medicine, Department of Biochemistry, Ankara Turkey

${ }^{2}$ Gazi University Faculty of Medicine, Department of Biophysics, Ankara, Turkey

${ }^{3}$ Gazi University Faculty of Medicine, Gazi Non-Ionizing Radiation Protection Center, Ankara, Turkey

\section{ABSTRACT}

Objective: With the development of technology human beings are increasingly under the exposure of electromagnetic fields, mainly radiofrequency radiation (RFR) from wireless technologies, mobile phones, base stations etc. There are many genotoxic effects, i.e. DNA and chromosome change studies related RFR exposures. There is still some uncertainty, no definitive conclusions have been reached so far. The aim of present study is to evaluate the genotoxicity studies about RFR exposure reported from 1989 to 2016.

Methods: The PubMed database from 1989 to 2016 was searched for "radiofrequency radiation" and "genotoxicity tests". Genotoxicity studies performed under RFR exposure were selected and classified as reported significant effects and reported no significant effect.

Results: There were 53 genotoxic effects of RFR studies totally and 19 of them indicated genotoxic effects $(35,8 \%)$ and 34 of total studies reported no significant effect (64,2\%).

Conclusion: It is apparent that there is no consistent pattern that RFR exposure could induce genetic damages. However, one can conclude that under certain conditions of exposure, RFR could be genotoxic. Generally the genotoxic effect of short-term exposure to RFR have been studied up to date. Long-term exposure to RFR is increasing in the environment. So, long-term effect of repeated exposure to RFR should also be studied by taking into consideration the DNA repair processes in order to identify the biological mechanisms involved.

Key Words: Radio-frequency radiation (RFR), genotoxicity tests, comet assay, chromosome aberration, sister chromatid exchange, micronuclei

Received: 03.17.2017

\section{ÖZET}

Amaç: Teknolojinin gelişimi ile birlikte, kablosuz teknolojiler, cep telefonları, baz istasyonları gibi kaynaklardan yayılan radyo-frekans radyasyona (RFR) her geçen gün daha çok maruz kalınmaktadır. RFR'ın genotoksik etkileri vardır; DNA ve kromozom değişimleri gibi önemli genotoksik etkilere neden olabilmektedir. Bu çalışmanın amacı, 1989-2016 yılları arasında bildirilen RFR maruziyeti ile ilgili genotoksisite çalışmalarını değerlendirmektir.

Yöntem: PubMed veritabanı, 1989-2016 yılları arasında "radyo frekans radyasyon" ve "genotoksisite testleri" için araştırılmıştır. RFR maruziyeti altında yapılan genotoksisite çalışmaları seçilmiş ve bildirilen önemli etkiler olarak sınıflandırılmıştır.

Bulgular: Toplam RFR çalışmalarında 53 genotoksik etki çalışması mevcuttu; bunların 19'unda genotoksik etkiler $(\% 35,8)$ bildirmiş ve 34 'ünde anlamlı bir etki bildirilmemiş̧ir (\% 64,2).

Sonuç: RFR'ye maruz kalmanın genetik hasar oluşturabileceğine dair tutarlı bir model bulunmadığı açıktır. Bununla birlikte, belirli maruz kalma koşulları altında RFR'nin genotoksik olabileceği sonucuna varılabilir. Genellikle RFR'ye kısa süreli maruz kalmanın genotoksik etkisi bugüne kadar incelenmiştir. Günümüz insanları her geçen gün daha fazla RFR'ye uzun süreli maruz kalmaktadır. Bu nedenle, tekrarlayan RFR'ye maruz kalmanın uzun vadeli etkisi, ilgili biyolojik mekanizmaları tanımlamak için DNA onarım süreçleri göz önüne alınarak incelenmelidir.

Anahtar Sözcükler: Radyo-frekans radyasyon (RFR), genotoksisite testler, comet assay, kromozom aberasyon, kardeş kromatit değişimi, mikroçekirdek

Geliş Tarihi: 17.03.2017

Kabul Tarihi: 15.12 .2017 


\section{INTRODUCTION}

Radio-frequency radiation (RFR) exposure is available in almost all areas of daily life due to mobile phones, televisions, microwave ovens, base stations, etc. A series of experiments have been performed to investigate possible effects particularly genetic effects of exposure to RFR. There are at least several hundred published papers that report electromagnetic fields (EMF) can affect cellular oxidative processes, can lead to oxidative damage. Increased free radical activity and changes in enzymes involved in cellular oxidative processes are the most consistent effects observed in cells and animals after EMF exposure.

Toxicity to the genome can lead to a change in cellular functions, cancer, and cell death. The 'comet assay', also known as the 'single-cell gel electrophoresis assay' is the most frequently used technique to study RFRinduced DNA strand breaks. The alkaline comet assay is used to measure single-strand breaks and alkali-labile sites in the DNA molecule. Studies have been carried out to investigate chromosomal conformation and micronucleus formation in cells after exposure to EMF (1). RFR exposures many studies have been conducted regarding alleged health effects but there is still some uncertainty and no definitive conclusions have been reached so far (2). The aim of present study is to evaluate the genotoxic effects of RFR exposure studies reported were from 1989 to 2016.

\section{METHODS}

PubMed database was searched for the keywords "Radiofrequency radiation" and "genotoxicity" from 1989 to 2016. Genotoxic effects of RFR studies were selected and classified as reported effects and reported no effect(Table 1).

\section{RESULTS}

There were 53 genotoxic effects of RFR studies totally and 19 of them reported genotoxic effects $(35,8 \%)$ and 34 of total studies reported no significant effect $(64,2 \%)$.

\section{Genotoxic studies that reports effects}

Gandhi et al. (2015) have shown that the study participants comprised 63 persons with residences near a mobile phone tower, and 28 healthy controls matched for gender, age, alcohol drinking and occupational sub-groups. Genetic damage parameters of DNA migration length, damage frequency (DF) and damage index were significantly $(p=0.000)$ elevated in the sample group compared to respective values in healthy controls. The female residents $(n=25)$ of the sample group had significantly $(p=0.004)$ elevated DF than the male residents $(n=38)$. The linear regression analysis further revealed daily mobile phone usage, location of residence and power density as significant predictors of genetic damage (3). In 2013, Atlı Şekeroğlu et al. investigated the cytogenotoxic effects of $900 \mathrm{MHz}$ RFR and the effect of a recovery period after exposure to RFR on bone marrow cells of immature and mature rats. They exposed $900 \mathrm{MHz}$ RFR to immature and mature rats with electric field levels $28,1 \pm 4,8 \mathrm{~V} / \mathrm{m}$ and $20,0 \pm 3,2 \mathrm{~V} / \mathrm{m}$. Specific absorption rate (SAR) values were in the range of $0.38-0.78 \mathrm{~W} / \mathrm{kg}$, and $0.31-0.52 \mathrm{~W} / \mathrm{kg} 2 \mathrm{~h} /$ day for 45 days. Significant differences were observed in chromosome aberrations (CA), micronucleus (MN) frequency, mitotic index (MI) and ratio of polychromatic erythrocytes (PCE) in all treatment and recovery groups (4). Liu et al. (2013) conducted a $24 \mathrm{~h}$ intermittent exposure ( $5 \mathrm{~min}$ on and $10 \mathrm{~min}$ off) of a mouse spermatocyte-derived GC-2 cell line to $1800 \mathrm{MHz}$ Global System for Mobile Communication (GSM) signals at SAR of $1 \mathrm{~W} / \mathrm{kg}, 2 \mathrm{~W} / \mathrm{kg}$ or $4 \mathrm{~W} / \mathrm{kg}$. Through the use of formamidopyrimidine DNA glycosylase (FPG) in a modified comet assay, they determined that the extent of DNA migration was significantly increased at a SAR of $4 \mathrm{~W} / \mathrm{kg}$. Flow cytometry analysis demonstrated that levels of the DNA adduct 8-oxoguanine (8-oxoG) were also increased at a SAR of $4 \mathrm{~W} / \mathrm{kg}$. These increases were concomitant with similar increases in the generation of reactive oxygen species (ROS); these phenomena were mitigated by co-treatment with the antioxidant $\alpha$-tocopherol. However, no detectable DNA strand breakage was observed by the alkaline comet assay. They concluded, findings may imply the novel possibility that RFR with insufficient energy for the direct induction of DNA strand breaks may produce genotoxicity through oxidative DNA base damage in male germ cells (5).

Jiang et al.(2012) examined whether such AR could be induced in mice exposed to RFR. Mice were pre-exposed to $900 \mathrm{MHz}$ RFR at $120 \mu \mathrm{W} / \mathrm{cm}^{2}$ power density for 4 hours/day for 1, 3, 5, 7 and 14 days and then subjected to an acute dose of $3 \mathrm{~Gy} \gamma$-radiation. The primary DNA damage in the form of alkali labile base damage and single strand breaks in the DNA of peripheral blood leukocytes was determined using the alkaline comet assay.
The results indicated that the extent of damage in mice which were preexposed to RFR for 1 day and then subjected to $\gamma$-radiation was similar and not significantly different from those exposed to $\gamma$-radiation alone. However, mice which were pre-exposed to RFR for 3, 5, 7 and 14 days showed progressively decreased damage and was significantly different from those exposed to $\gamma$ radiation alone. This data indicated that RFR pre-exposure is capable of inducing AR (6). Çam and Seyhan N (2012) collected hair samples from eight healthy human subjects immediately before and after using a 900-MHz GSM mobile phone for 15 and $30 \mathrm{~min}$. Single-strand DNA breaks of hair root cells from the samples were determined using the 'comet assay'. They concluded that a short-term exposure (15 and $30 \mathrm{~min}$ ) to RFR (900-MHz) from a mobile phone caused a significant increase in DNA single-strand breaks in human hair root cells located around the ear at which is used for the phone communications (7). Karaca et al. (2012) studies the possible effects of RFR on brain cell cultures of a newborn mouse. Brain cell cultures were exposed to $10.715 \mathrm{GHz}$ with SAR $0.725 \mathrm{~W} / \mathrm{kg}$ for $6 \mathrm{~h}$ in 3 days at $25^{\circ} \mathrm{C}$ to check for the micronucleus $(\mathrm{MNi})$ assay and the expression of 11 proapoptotic and antiapoptotic genes. It was found that MNi rate increased 11-fold and STAT3 expression decreased 7-fold in the cell cultures that exposed to RFR. They concluded that cell phones which spread RFR may damage DNA and change gene expression in brain cells (8). Sannino et al. (2011) proved the influence of cell cycle on the adaptive response (AR) induced by the exposure of human blood lymphocytes to RFR. Human peripheral blood lymphocytes in $G(0)$-, $\mathrm{G}(1)$ - or S-phase of the cell cycle were exposed for 20 hours to an adaptive dose (AD) of $900 \mathrm{MHz}$ RFR at an average SAR of $1.25 \mathrm{~W} / \mathrm{kg}$. Then they were treated with a challenge dose (CD) of $100 \mathrm{ng} / \mathrm{ml}$ mitomycin $C(M M C)$. Unexposed and sham-exposed controls as well as cells treated with MMC alone were included in the study. The incidence of micronuclei (MN) was evaluated to determine the induction of AR. Study confirmed the observations reported in their previous investigation where AR was observed in human blood lymphocytes exposed to $A D$ of $R F$ in S-phase of the cell cycle and further suggested that the timing of $A D$ exposure of $R F$ is important to elicit $A R$ (9). The genotoxic potential of 3 T MRI scans for 22, 45, 67, and 89 min in cultured human lymphocytes was investigated by analyzing chromosome aberrations $(\mathrm{CA})$, micronuclei $(\mathrm{MN})$, and single-cell gel electrophoresis. Researchers observed a significant increase in the frequency of single-strand DNA breaks following exposure to a 3 T MRI. In addition, the frequency of both CAs and $\mathrm{MN}$ in exposed cells increased in a time-dependent manner. These results suggest that exposure to $3 \mathrm{~T} M R I$ induces genotoxic effects in human lymphocytes (10). A comet assay was used to determine whether 1.8-GHz RFR with SAR of $2 \mathrm{~W} / \mathrm{kg}$ can influence DNA repair in human B-cell lymphoblastoid cells exposed to doxorubicin (DOX). The results demonstrated that RFR could not directly induce DNA damage of human B-cell lymphoblastoid cells; DOX could significantly induce DNA damage of human B-cell lymphoblastoid cells with the dose-effect relationship, and there were special repair characteristics of DNA damage induced by DOX; E-E-E type combinative exposure could obviously influence DNA repair at $6 \mathrm{~h}$ and $12 \mathrm{~h}$ after exposure to DOX (11). Yao et al. (2008) examined whether superposing of electromagnetic noise could block or attenuate DNA damage and intracellular reactive oxygen species (ROS) increase of cultured human lens epithelial cells (HLECs) induced by acute exposure to $1.8 \mathrm{GHz}$ RFR of the Global System for Mobile Communications (GSM). They used a GSM signal at $1.8 \mathrm{GHz}(217 \mathrm{~Hz}$ amplitude-modulated) with SAR of $1,2,3$, and $4 \mathrm{~W} / \mathrm{kg}$. After $2 \mathrm{~h}$ of intermittent exposure, the ROS level was assessed by the fluorescent probe, 2',7'-dichlorodihydrofluorescein diacetate (DCFH-DA). DNA damage to HLECs was examined by alkaline comet assay and the phosphorylated form of histone variant $\mathrm{H} 2 \mathrm{AX}$ (gammaH2AX) foci formation assay. After exposure to $1.8 \mathrm{GHz}$ RFR for $2 \mathrm{~h}$, HLECs exhibited significant intracellular ROS increase in the 2,3 , and $4 \mathrm{~W} / \mathrm{kg}$ groups. RFR at the SAR of $3 \mathrm{~W} / \mathrm{kg}$ and $4 \mathrm{~W} / \mathrm{kg}$ could induce significant DNA damage, examined by alkaline comet assay, which was used to detect mainly single strand breaks (SSBs), while no statistical difference in double strand breaks (DSBs), evaluated by gammaH2AX foci, was found between RF exposure (SAR: 3 and $4 \mathrm{~W} / \mathrm{kg}$ ) and sham exposure groups (12). Yao K et al. (2008) studied the influence of the 1.8-GHz RFR of the Global System for Mobile Communications on DNA damage, intracellular reactive oxygen species (ROS) formation, cell cycle, and apoptosis in human lens epithelial cells (hLECs). After 24-hour intermittent exposure at SAR of $1 \mathrm{~W} / \mathrm{kg}, 2 \mathrm{~W} / \mathrm{kg}, 3 \mathrm{~W} / \mathrm{kg}$, and $4 \mathrm{~W} / \mathrm{kg}$, the DNA damage of hLECs was examined by alkaline comet assay. DNA damage examined by alkaline comet assay was significantly increased after $3 \mathrm{~W} / \mathrm{kg}$ and $4 \mathrm{~W} / \mathrm{kg}$ radiation $(P<0.05)$, whereas the double-strand breaks (DSBs) evaluated by gamma $\mathrm{H} 2 \mathrm{AX}$ foci were significantly increased only after $4 \mathrm{~W} / \mathrm{kg}$ radiation $(\mathrm{P}<$ 0.05) (13). In 2008 Schwarz C et al. studied human cultured fibroblasts of three different donors; three different short-term human lymphocyte cultures were exposed to $1950 \mathrm{MHz}$ RFR with SAR of $2 \mathrm{~W} / \mathrm{kg}$. 
Table 1. Radio-frequency radiation (RFR) exposure and genotoxicity tests studies that reported effects

\begin{tabular}{|c|c|c|c|c|c|}
\hline Studies & Exposure & RF- EMF & SAR & Genotoxicity tests & Sample \\
\hline Gandhi et al. (2015) (3) & 63 persons & mobile phone tower & & DNA migration length & \\
\hline Atlı Şekeroğlu et al. (2013)(4) & immature and mature rats & $900 \mathrm{MHz}$ (RF-EMF) & $\begin{array}{l}0.38-0.78 \mathrm{~W} / \mathrm{kg} \text {, and } \\
0.31-0.52 \mathrm{~W} / \mathrm{kg} 2 \mathrm{~h} / \text { day } \\
\text { for } 45 \text { days }\end{array}$ & $\begin{array}{l}\text { Chromosome } \\
\text { aberrations (CA), } \\
\text { Micronucleus (MN) }\end{array}$ & (PCE) \\
\hline Liu et al. (2013)(5) & $\begin{array}{l}\text { mouse spermatocyte-derived } \\
\text { GC- } 2 \text { cell line }\end{array}$ & \multicolumn{3}{|c|}{$\begin{aligned} 1800 \mathrm{MHz}(\mathrm{GSM}) \text { signals } & 1 \mathrm{~W} / \mathrm{kg}, 2 \mathrm{~W} / \mathrm{kg} \text { or } 4 \mathrm{~W} / \mathrm{kg} \text { Comet assay } \\
& 24 \mathrm{~h} \text { intermittent exposure DNA adduct } \\
& (5 \mathrm{~min} \text { on and } 10 \mathrm{~min} \text { off) DNA strand breaks }\end{aligned}$} & GC- 2 cell line \\
\hline Jiang B et al. (2012)(6) & Mice & \multicolumn{2}{|c|}{$\begin{array}{l}900 \mathrm{MHz} R F \text { at } 120 \mu \mathrm{W} / \mathrm{cm}(2) \\
\text { power density for } 4 \text { hours/day } \\
\text { for } 1,3,5,7 \text { and } 14 \text { days and then. } \\
\text { subjected to an acute dose of } \\
3 \mathrm{~Gy} \gamma \text {-radiation }\end{array}$} & Alkaline comet assay & $\begin{array}{l}\text { peripheral } \\
\text { blood } \\
\text { leukocytes }\end{array}$ \\
\hline Çam ST and Seyhan N (2012)(7) & $\begin{array}{l}\text { Hair samples } \\
\text { for } 15 \text { and } 30 \mathrm{~min}\end{array}$ & \multicolumn{2}{|c|}{ 900-MHz GSM mobile phone } & $\begin{array}{l}\text { Comet assay } \\
\text { DNA single- } \\
\text { strand break }\end{array}$ & $\begin{array}{l}\text { human hair } \\
\text { root cells }\end{array}$ \\
\hline Karaca E et al. (2012)(8) & Brain cell cultures of the mice & $10.715 \mathrm{GHz}$ & $\begin{array}{l}0.725 \mathrm{~W} / \mathrm{kG} \text { signals } \\
\text { for } 6 \mathrm{~h} \text { in } 3 \text { days }\end{array}$ & $\begin{array}{l}\text { Micronucleus (MN) } \\
\text { expression of } 11 \\
\text { proapoptotic } \\
\text { and antiapoptotic genes }\end{array}$ & Brain cells \\
\hline Sannino A et al. (2011)(9) & $\begin{array}{l}\text { Human peripheral } \\
\text { blood lymphocytes } \\
\text { in } \mathrm{G}(0)-, \mathrm{G}(1) \text { - or } \\
\text { S-phase of the cell cycle }\end{array}$ & $\begin{array}{l}900 \mathrm{MHz} \mathrm{RF}+ \\
100 \mathrm{ng} / \mathrm{ml} \\
\text { mitomycin C }\end{array}$ & $\begin{array}{l}1.25 \mathrm{~W} / \mathrm{kg} \\
20 \text { hours }\end{array}$ & Micronuclei (MN) & $\begin{array}{l}\text { Human } \\
\text { peripheral } \\
\text { blood } \\
\text { lymphocytes }\end{array}$ \\
\hline Lee JW et al. (2011)(10) & Cultured human lymphocytes & \multicolumn{2}{|c|}{$\begin{array}{l}3 \mathrm{~T} \text { clinical MRI scans } \\
\text { for } 22,45,67 \text {, and } 89 \mathrm{~min}\end{array}$} & $\begin{array}{l}\text { chromosome aberrations (CA), } \\
\text { micronuclei (MN), } \\
\text { single-cell gel electrophoresis, } \\
\text { single-strand DNA breaks }\end{array}$ & $\begin{array}{l}\text { Human } \\
\text { lymphocytes }\end{array}$ \\
\hline Zhijian C et al. (2010)(11) & $\begin{array}{l}\text { Human B-cell lymphoblastoid cells } \\
\text { Doxorubicin }\end{array}$ & 1.8-GHz RFR + & $2 \mathrm{~W} / \mathrm{kg}$ & comet assay & $\begin{array}{l}\text { Human B-cell } \\
\text { lymphoblastoid }\end{array}$ \\
\hline Yao K et al. (2008)(12) & Cultured human lens epithelial cells & $1.8 \mathrm{GHz}$ RF GSM & $3 \mathrm{~W} / \mathrm{kg}$ and $4 \mathrm{~W} / \mathrm{kg}$ & $\begin{array}{l}\text { alkaline comet assay } \\
\text { single strand breaks }\end{array}$ & $\begin{array}{l}\text { human lens epithelial } \\
\text { cells }\end{array}$ \\
\hline Yao K et al. (2008)(13) & human lens epithelial cells & $1.8 \mathrm{GHz}$ RF GSM & $\begin{array}{l}1 \mathrm{~W} / \mathrm{kg}, 2 \mathrm{~W} / \mathrm{kg}, 3 \mathrm{~W} / \mathrm{kg} \text {, } \\
\text { and } 4 \mathrm{~W} / \mathrm{kg}\end{array}$ & $\begin{array}{l}\text { alkaline comet assay, } \\
\text { double-strand breaks } \\
\text { immunofluorescence } \\
\text { microscope } \\
\text { apoptosis }\end{array}$ & $\begin{array}{l}\text { human lens epithelial } \\
\text { cells }\end{array}$ \\
\hline Schwarz C et al. (2008)(14) & Human cultured fibroblasts & 1,950 MHz UMTS & $2 \mathrm{~W} / \mathrm{kg}$ & $\begin{array}{l}\text { alkaline comet assay, } \\
\text { micronucleus }\end{array}$ & Human fibroblast \\
\hline Trosic I and Busljeta I(2006)(15) & $\begin{array}{l}\text { Rats polychromatic erythrocytes } \\
\text { (PCEs), bone marrow (BM) }\end{array}$ & $\begin{array}{l}\text { (RF/MW) } 2.45 \mathrm{GHz} \\
\text { 2h/day, } 7 \text { days/week }\end{array}$ & $1.25+/-0.36 \mathrm{~W} / \mathrm{kg}$ & micronucleated & PCE, BM \\
\hline Baohong W et al. (2005)(16) & $\begin{array}{l}\text { human lymphocytes } \\
\text { mitomycin C, } \\
\text { bleomycin, } \\
\text { MMS, 4NQO }\end{array}$ & $1.8 \mathrm{GHz}$ RFR + & $3 \mathrm{~W} / \mathrm{kg}$ & comet assay & human lymphocytes \\
\hline Busljeta I et al. (2004)(17) & erythropoietic changes in rats & $\begin{array}{l}\text { (RF/MW) irradiation } \\
\text { at nonthermal level } \\
2.45 \mathrm{GHz} \text { continuous } \\
\mathrm{RF} / \mathrm{MW} \text { fields for } \\
\text { hours daily, } 7 \text { days a we }\end{array}$ & $5-10 \mathrm{~mW} / \mathrm{cm} 2$ & micronucleus (MN) & $\begin{array}{l}\text { peripheral blood } \\
\text { bone marrow }\end{array}$ \\
\hline Trosic I et al. (2004)(18) & bone marrow red cells of rats & $\begin{array}{l}2.45 \mathrm{GHz} \text { continuous } \mathrm{R} \\
\text { field for } 2 \mathrm{~h} \text { daily, } 7 \mathrm{da}\end{array}$ & $\begin{array}{l}\text { /MW } 1.25+/-0.36 \text { (SE)W/ } \\
\text { s a week }\end{array}$ & /kg micronuclei PCEs & bone marrow \\
\hline Trosic I et al. (2002)(19) & Wistar rats (PCEs) & $\begin{array}{l}2,450 \mathrm{MHz} \text { (rf/MW) } \\
2 \mathrm{~h} \text { a day, } 7 \text { days a wee } \\
\text { for up to } 30 \text { days }\end{array}$ & $5-10 \mathrm{~mW} / \mathrm{cm}(2)$ & micronuclei PCEs & $\begin{array}{l}\text { Peripheral blood } \\
\text { lymphocytes }\end{array}$ \\
\hline Garaj-Vrhovac V (1999)(20) & peripheral blood lymphocytes & (RFR) (MW) & & micronuclei (MN) & lymphocytes \\
\hline
\end{tabular}


The alkaline comet assay and the micronucleus assay were used to ascertain dose and time-dependent genotoxic effects. Universal Mobile Telecommunication System (UMTS) exposure increased the comet tail factor (CTF) and induced centromere-negative micronuclei (MN) in human cultured fibroblasts in a dose and time-dependent way. UMTS exposure may cause genetic alterations in some but not in all human cells in vitro (14).

Trosic et al. (2006) exposed rats $2 \mathrm{~h} /$ day, 7 days/week to $2450-\mathrm{MHz}$ microwaves at a whole-body SAR of $1.25+/-0.36 \mathrm{~W} / \mathrm{kg}$. Control animals were included in the study. Bone marrow micronucleus frequency was increased on experimental day 15 , and polychromatic erythrocytes micronucleus frequency in the peripheral blood was increased on day 8 (15). Banhong et al (2005) was performed to study the synergistic DNA damage effects in human lymphocytes induced by $1.8 \mathrm{GHz} \mathrm{RFR}$, SAR of $3 \mathrm{~W} / \mathrm{kg}$ with four chemical mutagens, mitomycin C, bleomycin, methyl methanesulfonate, and 4-nitroquinoline-1oxide. DNA damage of lymphocytes exposed to RFR and/or with chemical mutagens was detected at two incubation time ( 0 or $21 \mathrm{~h}$ ) after treatment with comet assay in vitro. The experimental results indicated $1.8 \mathrm{GHz}$ RFR (SAR, $3 \mathrm{~W} / \mathrm{kg}$ ) for $2 \mathrm{~h}$ did not induce the human lymphocyte DNA damage effects in vitro, but could enhance the human lymphocyte DNA damage effects induced by MMC and $4 \mathrm{NQO}$ (16). Busljeta et al. (2004) exposed male rats to $2.45 \mathrm{GHz}$ RFR fields for $2 \mathrm{~h} /$ day, 7 days/week, at $5-10 \mathrm{~mW} / \mathrm{cm}^{2}$ for up to 30 days. Erythrocyte count, haemoglobin and haematocrit were increased in peripheral blood on irradiation days 8 and 15 . Anuclear cells and erythropoietic precursor cells were significantly decreased in the bone marrow on day 15, but micronucleated cells were increased (17).Trosic et al. (2004) investigated increased micronucleus frequency in bone marrow red cells of rats exposed to a 2450- $\mathrm{MHz}$ continuous-wave microwaves for $2 \mathrm{~h}$ daily, 7 days a week, at a power density of $5-10 \mathrm{~mW} / \mathrm{cm}^{2}$ (whole body SAR 1.25 $+/-0.36$ (SE) W/kg) (18). Trosic et al. (2002) exposed adult male Wistar for $2 \mathrm{~h}$ a day, 7 days a week for up to 30 days to continuous $2450-\mathrm{MHz}$ microwaves at a power density of $5-10 \mathrm{~mW} / \mathrm{cm}^{2}$. Frequency of micronuclei in polychromatic erythrocytes showed a significant increase in the exposed animals after 2, 8 and 15 days of exposure compared to sham-exposed control (19). GarajVrhovac et al. (1999) examined peripheral blood lymphocytes of 12 subjects occupationally exposed to microwave radiation and showed an increase in frequency of micronuclei as well as disturbances in the distribution of cells over the first, second and third mitotic division in exposed subjects compared to controls (20).

\section{Genotoxicity tests studies that reported no significant effects}

Zhu et al.(2016) have shown that extremely low frequency magnetic fields do not induce DNA damage in human lense epithelial cells in vitro. Human LECs were exposed or sham-exposed to a $50 \mathrm{~Hz}$ ELF MF which produced by a well-designed exposure system at the intensity of $0.4 \mathrm{mT}$. DNA damage in human LECs was examined by the phosphorylated form of histone variant $\mathrm{H} 2 \mathrm{AX}(\mathrm{\gamma H} 2 \mathrm{AX})$ foci formation assay and further explored with western blot, flow cytometry, and alkaline comet assay (21). Kumar et al. (2015) reported reported that $900 / 1800 \mathrm{MHz}$ continuous wave (CW) RFR exposure 2/10 and 2.5/12.4 W/kg specific absorption rate SAR had no significant effect on the hematopoietic system of rats in the bone marrow (22). Speit et al. (2013) reported no genotoxic effects of RFR in human lymphoblastoid cell line HL-60 cells. Genotoxic effects of RFR were measured by means of the comet assay and the micronucleus test (23). Vijayalaxmi et al. (2013) collected peripheral blood samples from four healthy volunteers and aliquots were exposed in vitro for $2 \mathrm{~h}$ to either (i) modulated or unmodulated continuous wave (CW) $2450 \mathrm{MHz}$ RFR with SAR of $10.9 \mathrm{~W} / \mathrm{kg}$. Aliquots of the same samples that were exposed in vitro to an acute dose of $1.5 \mathrm{~Gy}$ ionizing gamma-radiation (GR) were used as positive controls. The results indicated the following: (i) the incidence of $\mathrm{MN}$ was similar in incubator control and those exposed to RFR/sham and Melatonin alone; (ii) there were no significant differences between WCDMA and CW- RFR exposures; (iii) positive control cells exposed to GR alone exhibited significantly increased $\mathrm{MN}$; and (iv) Melatonin treatment had no effect on cells (24). Waldmann et al. (2013) studied the possible genotoxic effect of RFR (GSM, 1,800 MHz) in human lymphocytes, it was investigated by a collaboration of six independent institutes (institutes a, b, $c, d, e, h)$. Peripheral blood of 20 healthy, nonsmoking volunteers of two age groups (10 volunteers $16-20$ years old and 10 volunteers $50-65$ years old) was taken, stimulated and intermittently exposed to three SARs of RFR $(0.2$ $\mathrm{W} / \mathrm{kg}, 2 \mathrm{~W} / \mathrm{kg}, 10 \mathrm{~W} / \mathrm{kg}$ ) and sham for $28 \mathrm{~h}$. Four genotoxicity tests with different end points were conducted: chromosome aberration test, micronucleus test, sister chromatid exchange test and the alkaline comet assay. On the basis of these specifications, none of the nine end points tested for SAR trend showed a significant and reproducible exposure effect (25). Jiang et al. (2013) used adult male ICR mice which were pre-exposed to nonionizing RFR, $900 \mathrm{MHz}$ at $120 \mu \mathrm{W} / \mathrm{cm}^{2}$ power density for $4 \mathrm{~h} /$ day for 7 days (adaptation dose, $A D$ ) and then subjected to an acute whole body dose of $3 \mathrm{~Gy}$ $\gamma$-radiation (challenge dose, $C D$ ).
The classical micronucleus (MN) assay was used to determine the extent of genotoxicity in immature erythrocytes in peripheral blood and bone marrow. The results indicated that in both tissues, the MN indices were similar in un-exposed controls (26). Ros-Llor et al. (2012) examined effect of mobile phones on micronucleus frequency in human exfoliated oral mucosal cells, they collected two cell samples from each subject, corresponding to the right and left cheek mucosa and found no statistically significant changes in relation to age, gender, body mass index, or smoking status (27). Trosić et al. (2011) evaluated DNA damage in rat's renal, liver and brain cells after in vivo exposure to RFR with a single cell gel electrophoresis/comet assay. Wistar rats were exposed to $915 \mathrm{MHz}$ RFR with power density of $2.4 \mathrm{~W} / \mathrm{m}^{2}$, SAR of 0.6 $\mathrm{W} / \mathrm{kg}$. The animals were irradiated for one hour/day, 7 days/week during two weeks. The results suggest that, repeated $915 \mathrm{MHz}$ irradiation could be a cause of DNA breaks in renal and liver cells, but not affect the cell genome at the higher extent compared to the basal damage (28). Sannino et al. (2009) investigated DNA damage in human dermal fibroblasts from a healthy subject and from a subject affected by Turner's syndrome that were exposed for $24 \mathrm{~h}$ to RFR at $900 \mathrm{MHz}$. RFR exposure was carried out alone or in combination with 3-chloro-4-(dichloromethyl)-5-hydroxy-2(5H)-furanone (MX). Turner's syndrome fibroblasts were also exposed for a shorter time $(1 \mathrm{~h})$. To evaluate DNA damage after RFR exposure alone, the alkaline comet assay and the cytokinesis-block micronucleus assay were used. In the combined-exposure experiments, MX was given at a concentration of 25 microM for $1 \mathrm{~h}$ immediately after the RFR exposure, and the effects were evaluated by the alkaline comet assay. The results revealed no genotoxic and cytotoxic effects from RF radiation alone in either cell line (29). Zhijian et al. (2009) used in vitro comet assay was used to determine whether 1.8-GHz RFR can influence DNA repair in human leukocytes exposed to X-rays. The SAR of $2 \mathrm{~W} / \mathrm{kg}$ was applied. The leukocytes from four young healthy donors were intermittently exposed to RFR for $24 \mathrm{~h}$ (fields on for $5 \mathrm{~min}$, fields off for $10 \mathrm{~min}$ ), and then irradiated with X-rays at doses of $0.25,0.5,1.0$ and $2.0 \mathrm{~Gy}$. DNA damage to human leukocytes was detected using the comet assay at $0,15,45,90,150$ and 240 min after exposure to X-rays. Using the comet assay, the percent of DNA in the tail (\% tail DNA) served as the indicator of DNA damage. The results demonstrated that the DNA repair speeds of human leukocytes after X-ray exposure exhibited individual differences among the four donors and the intermittent exposures of 1.8-GHz RFR at the SAR of $2 \mathrm{~W} / \mathrm{kg}$ for $24 \mathrm{~h}$ did not directly induce DNA damage or exhibit synergistic effects with X-rays on human leukocytes (30). Luukkonen et al (2009) investigated the effects of 872 $\mathrm{MHz}$ RFR on intracellular reactive oxygen species (ROS) production and DNA damage at a relatively high SAR value $(5 \mathrm{~W} / \mathrm{kg})$. The experiments also involved combined exposure to RF radiation and menadione, a chemical inducing intracellular ROS production and DNA damage. No effects of the GSM signal were seen on either ROS production or DNA damage (31). Kim et al. (2008) studied in vitro assessment of clastogenicity of mobile-phone radiation (835 $\mathrm{MHz}$ ) RFR using the alkaline comet assay and chromosomal aberration test. No direct cytogenetic effect of 835-MHz RFR was found in the in vitro CA test. The combined exposure of the cells to RF-EMF in the presence of ethylmethanesulfonate (EMS) revealed a weak and insignificant cytogenetic effect when compared to cells exposed to EMS alone in CA test. Also, the comet assay results to evaluate the ability of RFR alone to damage DNA were nearly negative, although showing a small increase in tail moment (32). Zeni et al. (2008) investigated genotoxic effects in human leukocytes of $1950 \mathrm{MHz}$ with SAR of $2.2 \mathrm{~W} / \mathrm{kg}$. Primary DNA damage (strand breaks/alkali labile sites) was also investigated following $24 \mathrm{~h}$ of intermittent RFR exposures, by applying the alkaline single cell gel electrophoresis (SCG)/comet assay. Positive controls were included by treating cell cultures with Mitomycin- $C$ and methylmethanesulfonate for micronucleus and comet assays. The results indicate that intermittent exposures of human lymphocytes in different stages of cell cycle do not induce either an increase in micronucleated cells, or change in cell cycle kinetics (33). Juutilainen et al. (2007) examined genotoxicity of long-term exposure to RFR by measuring micronuclei in erythrocytes. In study A, female CBA/S mice were exposed for 78 weeks ( $1.5 \mathrm{~h} / \mathrm{d}, 5 \mathrm{~d} /$ week) to either a continuous $902.5 \mathrm{MHz}$ SAR of $1.5 \mathrm{~W} / \mathrm{kg}$. The results did not show any effects of RFR on micronucleus frequency in polychromatic or normochromatic erythrocytes (34). Chauhan et al. (2007) examined non-thermal RFR exposure effects in a series of human-derived cell lines (TK6, HL60 and Mono-Mac-6). Exponentially growing cells were exposed to intermittent ( $5 \mathrm{~min}$ on, $10 \mathrm{~min}$ off) $1.9 \mathrm{GHz}$ pulse-modulated RFR for $6 \mathrm{~h}$ at mean SAR of 0,1 and $10 \mathrm{~W} / \mathrm{kg}$. The cell culture supernatants were assessed for the presence of a series of human inflammatory cytokines (TNFA, IL1B, IL6, IL8, IL10, IL12) using a cytometric bead array assay. No detectable changes in cell viability, cell cycle kinetics, incidence of apoptosis, or cytokine expression were observed in any of RF-field-exposed groups in any of the cell lines tested, relative to the sham controls (35). Lixia et al. (2006) investigated the DNA damage, expression of heat shock protein 70 (Hsp70) and cell proliferation of human lens epithelial cells (hLEC) after exposure to the $1.8 \mathrm{GHz}$ RFR. 
An Xc-1800 RFR exposure system was used to employ a GSM signal at $1.8 \mathrm{GHz}$ ( $217 \mathrm{~Hz}$ amplitude-modulated) with the output power in the SAR of 1, 2 and 3 $\mathrm{W} / \mathrm{kg}$. The results indicate that exposure to non-thermal dosages of RFR for wireless communications can induce no or repairable DNA damage and the increased Hsp70 protein expression in hLECs occurred without change in the cell proliferation rate. The non-thermal stress response of $\mathrm{Hsp} 70$ protein increase to RFR exposure might be involved in protecting hLEC from DNA damage and maintaining the cellular capacity for proliferation (36). Scarfi et al (2006) exposed human peripheral blood lymphocytes to $900 \mathrm{MHz}$ GSM signal at SAR of $0,1,5$ and $10 \mathrm{~W} / \mathrm{kg}$ peak values. No significant change in micronucleus frequency was observed (37). Stronati et al. (2006) examined the possibility of genotoxicity of RFR applied alone or in combination with $x$ rays was investigated in vitro using several assays on human lymphocytes. Blood specimens from 14 donors were exposed continuously for $24 \mathrm{~h}$ to a GSM basic $935 \mathrm{MHz}$ signal. The signal was applied at two SAR; 1 and $2 \mathrm{~W} / \mathrm{Kg}$, alone or combined with a 1-min exposure to $1.0 \mathrm{~Gy}$ of $250 \mathrm{kVp}$ x-rays given immediately before or after the RFR. The assays employed were the alkaline comet technique to detect DNA strand breakage, metaphase analyses to detect unstable chromosomal aberrations and sister chromatid exchanges, micronuclei in cytokinesis-blocked binucleate lymphocytes and the nuclear division index to detect alterations in the speed of in vitro cell cycling. By comparison with appropriate sham-exposed and control samples, no effect of RFR alone could be found for any of the assay endpoints. In addition RFR did not modify any measured effects of the x-radiation (38). Vershaeve et al. (2006) used long-term exposure ( 2 hrs/day, 5 days/week for 2 years) of rats with $900 \mathrm{MHz}$ GSM signal at 0.3 and $0.9 \mathrm{~W} / \mathrm{kg}$ and proved that RFR exposure did not significantly affect levels of DNA strand breaks in cells. Maes et al. (2006) published a series of papers on in vitro genotoxic effects of RFR and interaction with chemicals. Their results show no significant effect. Sakuma et al. (2006) exposed human glioblastoma A172 cells and normal human IMR-90 fibroblasts from fetal lungs to mobile communication radiation for 2 and 24 hrs. No significant change in DNA strand breaks were observed up to 800 $\mathrm{mW} / \mathrm{kg}(39)$.

Maes A et al. (2006) investigated cytogenetic effects in peripheral blood lymphocytes from subjects who were professionally exposed to mobile phone electromagnetic fields in an attempt to demonstrate possible RFR-induced genetic effects. The alkaline comet assay, sister chromatid exchange (SCE) and chromosome aberration tests revealed no evidence of RFR-induced genetic effects. Blood cells were also exposed to the well known chemical mutagen mitomycin C in order to investigate possible combined effects of RFR and the chemical. No cooperative action was found between the electromagnetic field exposure and the mutagen using either the comet assay or SCE test (40). Sakuma $N$ et al. (2006) DNA strand breaks are not induced in human cells exposed to $2.1425 \mathrm{GHz}$ band CW and W-CDMA modulated radiofrequency fields allocated to mobile radio base stations. A172 cells were exposed to WCDMA radiation at SARs of 80,250 , and $800 \mathrm{~mW} / \mathrm{kg}$ and $\mathrm{CW}$ radiation at 80 $\mathrm{mW} / \mathrm{kg}$ for 2 and $24 \mathrm{~h}$, while IMR-90 cells were exposed to both W-CDMA and $\mathrm{CW}$ radiations at a SAR of $80 \mathrm{~mW} / \mathrm{kg}$ for the same time periods. Under the same RF field exposure conditions, no significant differences in the DNA strand breaks were observed between the test groups exposed to W-CDMA or CW radiation and the sham exposed negative controls, as evaluated immediately after the exposure periods by alkaline comet assays. Their results confirm that low level exposures do not act as a genotoxicant up to a SAR of $800 \mathrm{~mW} / \mathrm{kg}$ (41).

Nikolova T et al. (2005) used mouse embryonic stem (ES) cells were as an experimental model to study the effects of electromagnetic fields (EMF). ESderived nestin-positive neural progenitor cells were exposed to extremely low frequency EMF simulating power line magnetic fields at $50 \mathrm{~Hz}$ (ELF-EMF) and to RFR simulating GSM signals at $1.71 \mathrm{GHz}$ RFR. Short-term RFR exposure for $6 \mathrm{~h}$, but not for $48 \mathrm{~h}$, resulted in a low and transient increase of DNA doublestrand breaks. No effects of ELF-EMF and RFR on mitochondrial function, nuclear apoptosis, cell proliferation, and chromosomal alterations were observed (42). Diem et al (2005) exposed human fibroblasts and rat granulosa cells to mobile phone signal with frequency of $1800 \mathrm{MHz}$, SAR 1.2 or $2 \mathrm{~W} / \mathrm{kg}$, with different modulations; during 4, 16 and $24 \mathrm{~h}$; intermittent exposures with $5 \mathrm{~min}$ on/10min off or continuous. RFR exposure induced DNA single- and double-strand breaks as measured by the comet assay. Effects occurred after $16 \mathrm{~h}$ exposure in both cell types and after different mobile-phone modulations. The intermittent exposure showed a stronger effect in the than continuous exposure. They conclude that the induced DNA damage cannot be based on thermal effects (43). Hook et al. (2004) showed that 24-hr exposure of Molt-4 cells to different modulated RFR did not significantly alter the level of DNA damage. Bisht et al. (2002) examined if RFR induces the formation of micronuclei, C3H 10T(1/2) cells were exposed to $835.62 \mathrm{MHz}$ frequency division multiple access (FDMA) or $847.74 \mathrm{MHz}$ code division multiple access (CDMA) modulated RFR.
After the exposure to RFR, the micronucleus assay was performed by the cytokinesis block method using cytochalasin B treatment. The results of this study are not consistent with the possibility that these RFR induce micronuclei (44). Bisht KS et al. (2002) examined if radiofrequency (RF) radiation induces the formation of micronuclei, C3H 10T(1/2) cells were exposed to $835.62 \mathrm{MHz}$ frequency division multiple access (FDMA) or $847.74 \mathrm{MHz}$ code division multiple access (CDMA) modulated RFR. After the exposure to RFR, the micronucleus assay was performed by the cytokinesis block method using cytochalasin B treatment. The results of this study are not consistent with the possibility that these RFR induce micronuclei (45). Vijayalaximi et al. (2001) reported that there was no evidence for the induction of micronuclei in peripheral blood and bone marrow cells of rats exposed for $24 \mathrm{~h}$ to $2450-\mathrm{MHz}$ RFR at a whole body average SAR of $12 \mathrm{~W} / \mathrm{kg}$ (46). Li et al. (2001) reported no significant change in DNA strand breaks in murine C3H10T(1/2) fibroblasts after 2 hrs of exposure to 847.74 and $835.02 \mathrm{MHz}$ fields at 3-5 W/kg (47). Vijayalaxmi et al. (2000) collected human peripheral blood samples from three healthy human volunteers and samples were exposed in vitro to pulsed-wave $2450 \mathrm{MHz}$ RFR for $2 \mathrm{~h}$. The lymphocytes were examined to determine the extent of primary DNA damage (single-strand breaks and alkali-labile lesions) using the alkaline comet assay with three different slide-processing schedules. Under the experimental conditions tested, there is no evidence for induction of DNA single-strand breaks and alkali-labile lesions in human blood lymphocytes exposed in vitro to pulsed-wave $2450 \mathrm{MHz}$ RFR, either immediately or at $4 \mathrm{~h}$ after exposure (48). Maes et al. (1997) examined the genetic effects of RFR from mobile communication frequencies $(935.2 \mathrm{MHz})$ alone and in combination with a chemical DNA-damaging agent (mitomycin C). Three cytogenetic endpoints were investigated after in vitro exposure of human whole blood cells. These endpoints were the 'classical' chromosome aberration test, the sister chromatid exchange test and the alkaline comet assay. No direct cytogenetic effect was found (49). Vijayalaximi et al. (1997) exposed $\mathrm{C} 3 \mathrm{H} / \mathrm{HeJ}$ mice for $20 \mathrm{~h} /$ day, 7 days/week, over 18 months to continuous-wave $2450 \mathrm{MHz}$ RFR at a whole-body average SAR rate of 1.0 $\mathrm{W} / \mathrm{kg}$. At the end of the 18 months, peripheral blood and bone marrow smears were examined for the extent of genotoxicity as indicated by the presence of micronuclei in polychromatic erythrocytes. The results indicate that the incidence of micronuclei/1,000 polychromatic erythrocytes was not significantly different between groups exposed to RFR and sham-exposed groups (50). Meltz et al. (1987) performed the forward mutation assay at the thymidine kinase locus in L5178Y mouse leukemic cells. The power density was $48.8 \mathrm{~mW} / \mathrm{cm}^{2}$ and the measured SAR in this system was $30 \mathrm{~W} / \mathrm{kg}$. The conclusions from five different experiments, employing three different concentrations of MMC, were that a) RFR exposure alone, at moderate power levels which resulted in a temperature increase in the cell culture medium of less than 3 degrees $C$, is not mutagenic; and $b$ ) when cells are simultaneously treated with MMC and RFR at these same moderate power levels, the RFR does not affect either the inhibition of cell growth or the extent of mutagenesis resulting from the treatment with the chemical MMC alone (51). We have two reports which show no statistically significant difference between $1800 \mathrm{MHz}$ and $2100 \mathrm{MHz}$ RFR exposed groups with respect to nonexposed groups $(52,53)$.

\section{DISCUSSION}

The epidemiological evidence for a causal association between cancer and RFR exposure is weak and limited. Animal studies have provided no consistent evidence that exposure to RFR at non-thermal intensities causes or promotes cancer. Extensive in vitro studies have found no consistent evidence of genotoxic potential, but in vitro studies assessing the epigenetic potential of RFR exposure are limited. Overall, a weight-of-evidence evaluation shows that the current evidence for a causal association between cancer and exposure to RFR exposure is weak and unconvincing. However, the existing epidemiology is limited and the possibility of epigenetic effects has not been thoroughly evaluated, so that additional research in those areas will be required for a more thorough assessment of the possibility of a causal connection between cancer and the RFR exposure from mobile telecommunications (54). Comet assay was used in most of the EMF studies to determine DNA damage. Different versions of the assay have been developed. These versions have different detection sensitivities and can be used to measure different aspects of DNA strand breaks. Another concern is that most of the 'comet assay' studies were carried out by experimenters who had no prior experience on the assay. Comet assay is that it is a very sensitive assay and requires great care in performing. Thus, different detection sensitivities could result from different experimenters, even following the same procedures. Other endpoint tests were the 'classical' chromosome aberration test, the sister chromatid exchange test (1). 
Studies have also been carried out to investigate chromosomal conformation and micronucleus formation in cells after exposure to RFR. Attention is also paid to combined exposures of RFR with chemical or physical agents. Again, however, no entirely consistent picture emerges. Many of the positive studies may well be due to thermal exposures, but a few studies suggest that biological effects can be seen at low levels of exposure. Overall, however, the evidence for low-level genotoxic effects is very weak (2). A drawback in the interpretation and understanding of experimental data from bioelectromagnetic research is that there is no general acceptable mechanism on how RFR affects biological systems. The mechanism by which RFR causes genetic effect is unknown. Since the energy level is not sufficient to cause direct breakage of chemical bonds within molecules, the effects are probably indirect and secondary to other induced-chemical changes in the cell (1).

Our literature survey, since only $35.8 \%$ of the studies reported effects, it is apparent that there is no consistent pattern that RFR exposure could induce genetic damages/changes in cells and organisms. However, one can conclude that under certain conditions of exposure, RFR is genotoxic.

\section{Conflict of interest}

No conflict of interest was declared by the authors.

\section{REFERENCES}

1. Biolnitiative 2012, A Rationale for Biologically-based Exposure Standards for Low-Intensity Electromagnetic Radiation, section 6.

2. Verschaeve L, Juutilainen J, Lagroye I, Miyakoshi J, Saunders R, de Seze $R$, et al. In vitro and in vivo genotoxicity of radiofrequency fields. Mutat Res. 2010; 705:252-68.

3. Gandhi G, Kaur G, Nisar U. A cross-sectional case control study on genetic damage in individuals residing in the vicinity of a mobile phone base station. Electromagn Biol Med. 2015; 34:344-54.

4. Atlı Şekeroğlu Z, Akar A. Evaluation of the cytogenotoxic damage in immature and mature rats exposed to $900 \mathrm{MHz}$ radiofrequency electromagnetic fields. Int J Radiat Biol. 2013; 89: 985-92.

5. Liu C, Duan W, Xu S, Chen C, He M, Zhang L. et al. Exposure to 1800 $\mathrm{MHz}$ radiofrequency electromagnetic radiation induces oxidative DNA base damage in a mouse spermatocyte-derived cell line. Toxicol Lett. 2013; 218:2-9.

6. Jiang B, Nie J, Zhou Z, Zhang J, Tong J, Cao Y. Adaptive response in mice exposed to $900 \mathrm{MHz}$ radiofrequency fields: primary DNA damage. PLoS One. 2012; 7:e32040.

7. Çam ST, Seyhan N. Single-strand DNA breaks in human hair root cells exposed to mobile phone radiation. Int J Radiat Biol. 2012;88:420- 4.

8. Karaca E, Durmaz B, Aktug H, Yildiz T, Guducu C, Irgi M. et al. The genotoxic effect of radiofrequency waves on mouse brain. Neurooncol. 2012; 106:53-8.

9. Sannino A, Zeni O, Sarti M, Romeo S, Reddy SB, Belisario MA et al. Induction of adaptive response in human blood lymphocytes exposed to $900 \mathrm{MHz}$ radiofrequency fields: influence of cell cycle. Int J Radiat Biol. 2011;87:993-9.

10. Lee JW, Kim MS, Kim YJ, Genotoxic effects of $3 \mathrm{~T}$ magnetic resonance imaging in cultured human lymphocytes. Bioelectromagnetics. 2011;32:535-42.

11. Zhijian C, Xiaoxue L, Yezhen L, Shijie C, Lifen J, Jianlin L. et al. Impact of $1.8-\mathrm{GHz}$ radio-frequency radiation (RFR) on DNA damage and repair induced by doxorubicin in human B-cell lymphoblastoid cells. Mutat Res. 2010; 695:16-21.

12. Yao $K$, Wu W, Wang $K, \mathrm{Ni} \mathrm{S}, \mathrm{Ye} P, \mathrm{Yu}$ Y. et al. Electromagnetic noise inhibits radiofrequency radiation-induced DNA damage and reactive oxygen species increase in human lens epithelial cells. Mol Vis. 2008;14:964-9.

13. Yao K, Wu W, Yu Y, Zeng $Q$, He J, Lu D, Wang K. et al. Effect of superposed electromagnetic noise on DNA damage of lens epithelial cells induced by microwave radiation. Invest Ophthalmol Vis Sci. 2008 ;49: 2009-15.

14. Schwarz C, Kratochvil E, Pilger A, Kuster N, Adlkofer F, Rüdiger HW. et al. Radiofrequency electromagnetic fields (UMTS, $1,950 \mathrm{MHz}$ ) induce genotoxic effects in vitro in human fibroblasts but not in lymphocytes. Int Arch Occup Environ Health. 2008;81:755-67.

15. Trosic I, Busljeta I. Erythropoietic dynamic equilibrium in rats maintained after microwave irradiation. Exp Toxicol Pathol. 2006;57:247-51.

16. Baohong $W$, Jiliang $H$, Lifen J, Deqiang L, Wei $Z$, Jianlin L. et al. Studying the synergistic damage effects induced by $1.8 \mathrm{GHz}$ radiofrequency field radiation (RFR) with four chemical mutagens on human lymphocyte DNA using comet assay in vitro. Mutat Res. 2005; 578:149-57
17. Busljeta I, Trosic I, Milkovic-Kraus S. Erythropoietic changes in rats after $2.45 \mathrm{GJz}$ nonthermal irradiation. Int J Hyg Environ Health. 2004; 207:549-54

18. Trosic I, Busljeta I, Modlic B. Investigation of the genotoxic effect of microwave irradiation in rat bone marrow cells: in vivo exposure. Mutagenesis. 2004;19:361-4.

19. Trosic I, Busljeta I, Kasuba V, Rozgaj R. Micronucleus induction after whole-body microwave irradiation of rats.Mutat Res. 2002; 521:73-9.

20. Garaj-Vrhovac V. Micronucleus assay and lymphocyte mitotic activity in risk assessment of occupational exposure to microwave radiation. Chemosphere. 1999; 39:2301-12.

21. Zhu K, Lv Y, Cheng Q, Hua J, Zeng Q. Extremely Low Frequency Magnetic Fields Do Not Induce DNA Damage in Human Lens Epithelial Cells In Vitro. Anat Rec (Hoboken). 2016 ;299:688-97.

22. Kumar G, McIntosh RL, Anderson V, McKenzie RJ, Wood AW. A genotoxic analysis of the hematopoietic system after mobile phone type radiation exposure in rats. Int J Radiat Biol. 2015;91:664-72.

23. Speit G, Gminski R, Tauber R. Genotoxic effects of exposure to radiofrequency electromagnetic fields (RF-EMF) in HL-60 cells are not reproducible. Mutat Res. 2013; 755:163-6.

24. Vijayalaxmi, Reddy $A B$, McKenzie RJ, Mclntosh RL, Prihoda TJ, Wood AW. Incidence of micronuclei in human peripheral blood lymphocytes exposed to modulated and unmodulated $2450 \mathrm{MHz}$ radiofrequency fields. Bioelectromagnetics 2013; 34:542-8.

25. Waldmann $P$, Bohnenberger $S$, Greinert $\quad R$, Hermann-Then B, Heselich A, Klug SJ, et al. Influence of GSM signals on human peripheral lymphocytes: study of genotoxicity. Radiat Res.2013; 179:243-53

26. Jiang $\mathrm{B}$, Zong $\mathrm{C}$, Zhao $\mathrm{H}$, Ji $\mathrm{Y}$, Tong J, Cao $\mathrm{Y}$. Induction of adaptive response in mice exposed to $900 \mathrm{MHz}$ radiofrequency fields: application of micronucleus assay. Mutat Res. 2013; 751:127-9.

27. Ros-Llor I, Sanchez-Siles M, Camacho-Alonso F, Lopez-Jornet P. Effect of mobile phones on micronucleus frequency in human exfoliated oral mucosal cells. Oral Dis. 2012;18:786-92

28. Trosić I, Pavicić I, Milković-Kraus S, Mladinić M, Zeljezić D. Effect of electromagnetic radiofrequency radiation on the rats' brain, live and kidney cells measured by comet assay. Coll Antropol.2011; 35:1259-64

29. Sannino A, Di Costanzo G, Brescia F, Sarti M, Zeni O, Juutilainen J. et al. Human fibroblasts and $900 \mathrm{MHz}$ radiofrequency radiation: evaluation of DNA damage after exposure and co-exposure to 3 chloro-4-(dichloromethyl)-5-hydroxy-2(5h)-furanone (MX). Radiat Res. 2009; 171:743-51.

30. Zhijian C, Xiaoxue L, Yezhen L, Deqiang L, Shijie C, Lifen J.et al.Influence of 1.8-GHz (GSM) radio-frequency radiation (RFR) on DNA damage and repair induced by X-rays in human leukocytes in vitro. Mutat Res. 2009; 677:100-4

31. Luukkonen J, Hakulinen $P$, Mäki-Paakkanen J, Juutilainen J, Naarala J. Enhancement of chemically induced reactive oxygen species production and DNA damage in human SH-SY5Y neuroblastoma cells by $872 \mathrm{MHz}$ radiofrequency radiation. Mutat Res. 2009;662: 54-8.

32. Kim JY, Hong SY, Lee YM, Yu SA, Koh WS, Hong JR. et al. In vitro assessment of clastogenicity of mobile-phone radiation (835 MHz) using the alkaline comet assay and chromosomal aberration test. Environ Toxicol. 2008; 23:319-27.

33. Zeni O, Schiavoni A, Perrotta A, Forigo D, Deplano M, Scarfi MR Evaluation of genotoxic effects in human leukocytes after in vitro exposure to $1950 \mathrm{MHz}$ UMTS radiofrequency field. Bioelectromagnetics. 2008; 29:177-84.

34. Juutilainen J, Heikkinen P, Soikkeli H, Mäki-Paakkanen J. Micronucleus frequency in erythrocytes of mice after long-term exposure to radiofrequency radiation. Int J Radiat Biol. 2007, 83:213-20.

35. Chauhan V, Mariampillai A, Kutzner BC, Wilkins RC, Ferrarotto C, Bellier PV. et al. Evaluating the biological effects of intermittent 1.9 GHz pulse-modulated radiofrequency fields in a series of human-derived cell lines. Radiat Res. 2007; 167:87-93.

36. Lixia $S$, Yao K, Kaijun W, Deqiang L, Huajun $H$, Xiangwei $G$. et al. Effects of $1.8 \mathrm{GHz}$ radiofrequency field on DNA damage and expression of heat shock protein 70 in human lens epithelial cells. Mutat Res. 2006; 602:135-42.

37. Scarfi MR, Fresegna AM, Villani $P$, Pinto $R$, Marino $C$, Sarti M. et al. Exposure to radiofrequency radiation ( $900 \mathrm{MHz}, \mathrm{GSM}$ signal) does not affect micronucleus frequency and cell proliferation in human peripheral blood lymphocytes: an interlaboratory study. Radiat Res. 2006; 165:655-63. 
38. Stronati L, Testa A, Moquet J, Edwards A, Cordelli E, Villani P. et al. $935 \mathrm{MHz}$ cellular phone radiation. An in vitro study of genotoxicity in human lymphocytes. Int J Radiat Biol. 2006; 82:339-46.

39. Verschaeve L, Heikkinen P, Verheyen G, Van Gorp U, Boonen $F$, Vander Plaetse F. et al. Investigation of co-genotoxic effects of radiofrequency electromagnetic fields in vivo. Radiat Res. 2006; 165:598-607.

40. Maes A, Van Gorp U, Verschaeve L. Cytogenetic investigation of subjects professionally exposed to radiofrequency radiation. Mutagenesis. 2006; 21:139-42.

41. Sakuma N, Komatsubara $Y$, Takeda H, Hirose H, Sekijima M, Nojima T. et al. DNA strand breaks are not induced in human cells exposed to $2.1425 \mathrm{GHz}$ band CW and W-CDMA modulated radiofrequency fields allocated to mobile radio base stations. Bioelectromagnetics. 2006; 27:51-7.

42. Nikolova T, Czyz J, Rolletschek A, Blyszczuk P, Fuchs J, Jovtchev G. et al. Electromagnetic fields affect transcript levels of apoptosisrelated genes in embryonic stem cell-derived neural progenitor cells. FASEB J. 2005; 19:1686-8.

43. Diem E, Schwarz $C$, Adlkofer $F$, Jahn $O$, Rüdiger $H$. Non-thermal DNA breakage by mobile-phone radiation (1800 MHz) in human fibroblasts and in transformed GFSH-R17 rat granulosa cells in vitro. Mutat Res. 2005; 583:178-83.

44. Hook GJ, Zhang P, Lagroye I, Higashikubo R, Moros EG, Straube WL et al. Measurement of DNA damage and apoptosis in Molt-4 cells after in vitro exposure to radiofrequency radiation Radiat Res. 2004;161:193-200.

45. Bisht KS, Moros EG, Straube WL, Baty JD, Roti JL. The effect of 835.62 $\mathrm{MHz}$ FDMA or 847.74 $\mathrm{MHz}$ CDMA modulated radiofrequency radiation on the induction of micronuclei in $\mathrm{C} 3 \mathrm{H}$ 10T(1/2) cells. Radiat Res. 2002;157:506-15. 2018; 29: 87-93 MC. et al. Micronuclei in the peripheral blood and bone marrow cells of rats exposed to $2450 \mathrm{MHz}$ radiofrequency radiation. Int J Radiat Biol. 2001;77:1109-15.

47. Li L, Bisht KS, LaGroye I, Zhang P, Straube WL, Moros EG. et al. Measurement of DNA damage in mammalian cells exposed in vitro to radiofrequency fields at SARs of $3-5 \mathrm{~W} / \mathrm{kg}$. Radiat Res. 2001;156:328-32

48. Vijayalaxm, Leal BZ, Szilagyi M, Prihoda TJ, Meltz ML Primary DNA damage in human blood lymphocytes exposed in vitro to $2450 \mathrm{MHz}$ radiofrequency radiation. Radiat Res. 2000; 153:479-86.

49. Maes A, Collier M, Van Gorp U, Vandoninck S, Verschaeve L. Cytogenetic effects of 935.2-MHz (GSM) microwaves alone and in combination with mitomycin C. Mutat Res. 1997; 393:151-6.

50. Vijayalaxmi, Frei MR, Dusch SJ, Guel V, Meltz ML, Jauchem JR Frequency of micronuclei in the peripheral blood and bone marrow of cancer-prone mice chronically exposed to $2450 \mathrm{MHz}$ radiofrequency radiation. Radiat Res. 1997; 147:495-500.

51. Meltz ML, Eagan P, Erwin DN. Absence of mutagenic interaction between microwaves and mitomycin $\mathrm{C}$ in mammalian cells. Environ Mol Mutagen. 1989; 13:294-303.

52. Gurbuz N, Sirav B, Colbay M, Yetkin I, Seyhan N. No genotoxic effect in exfoliated bladder cells of rat under the exposure of 1800 and $2100 \mathrm{MHz}$ radio-frequency radiation. Electromagn Biol Med. 2014;33:296-301.

53. Gurbuz N, Sirav B, Yuvaci HU, Turhan N, Coskun ZK, Seyhan N. Is there any possible genotoxic effect in exfoliated bladder cells of rat under the exposure of $1800 \mathrm{MHzGSM}$-like modulated radiofrequency radiation (RFR)? Electromagn Biol Med. 2010;29:98-104.

54. Moulder JE, Foster KR, Erdreich LS, McNamee JP. Mobile phones, mobile phone base stations and cancer: a review. Int J Radiat Biol. 2005;8 1:189-203. 